УДК 621.983 .07

Каргин Б. С. Каргин С. Б.

Ашихмин А. $\Gamma$.

\title{
ВЛИЯНИЕ ФОРМЫ РАБОЧЕЙ ГРАНИ ПУАНСОНА И ТЕХНОЛОГИЧЕСКОЙ СМАЗКИ НА ЭНЕРГОСИЛОВЫЕ ПАРАМЕТРЫ ВЫРУБКИ-ПРОБИВКИ
}

Экономическая целесообразность использования листовой штамповки в значительной мере определяется стоимостью штампов, приходящейся на единицу изделия, величина которой, в основном, обуславливается их стойкостью.

Высокая стойкость штампов является основным условием рентабельности работы штамповочных цехов. Она в значительной степени определяет себестоимость и качество изделий.

Первоначальные расходы на штамповочный инструмент на некоторых заводах достигают $25 \%$ от общей себестоимости продукции. Увеличение стойкости штампов повышает производительность труда и культуру производства $[1,2]$. Следовательно, повышение стойкости вырубных штампов является актуальной задачей, в особенности в условиях современного автоматизированного производства.

Стойкость разделительных штампов зависит от многих факторов; к малоизученным относится форма рабочей грани пуансона и влияние контактных условий на энергосиловые параметры [3]. На рис. 1 приведены различные типы пуансонов [4].

Цель исследования - установить зависимость стойкости штампов от конфигурации пуансона и наличия технологической смазки (ТC) при разделительных операциях листовой штамповки. Эксперименты проводились на разрывной машине Р-20.
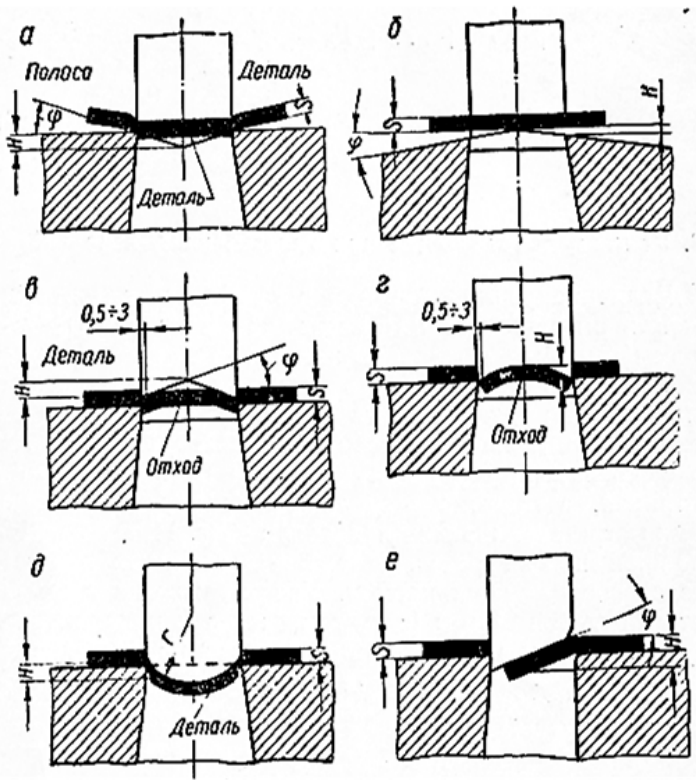

Рис. 1. Различные типы скосов ножей

В данной работе приведены результаты лабораторных исследований вышеуказанных параметров при пробивке отверстий диаметром 52 мм в листовой стали Ст 3 пп толщиной 2 мм.

Принято, что снижение силовых параметров на рабочие грани пуансона позволяет повысить стойкость штампов. 
Пуансоны имели следующую форму: плоский; с односторонним наклоном рабочей режущей кромки $\left(\alpha=15^{\circ}\right)$; с двусторонним наклоном режущих кромок внутрь $\left(\alpha=\alpha=15^{\circ}\right)$; с рифленой рабочей боковой поверхностью. При этом шаг рифлений принят $t=0,5 \mathrm{MM}, t=1 \mathrm{мм}$ при угле профиля $70^{\circ}$ (рис. 2). Шлифованные и рифленые пуансоны изготовлялись из стали У8А. Термообработка пуансонов производилась по технологии: закалка до твердости HRC 60, низкотемпературный отпуск до твердости HRC 56-59. После термообработки производилась шлифовка посадочной части и торцов пуансонов.

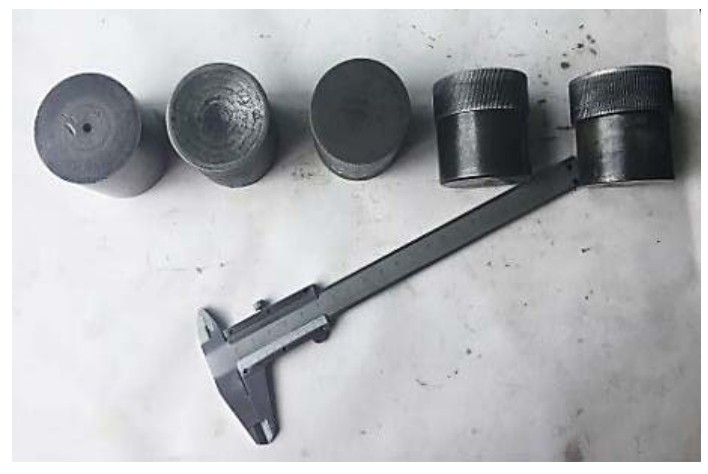

a

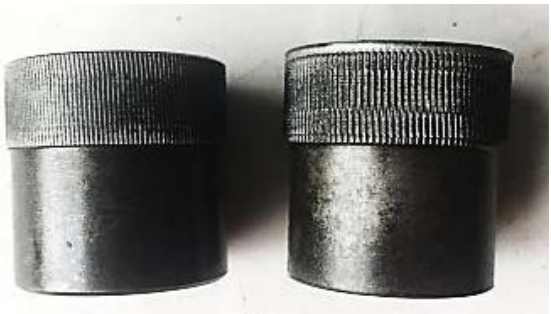

6

Рис. 2. Конфигурации пуансонов:

a - пуансон с различной формой рабочей грани; б - пуансон с рифленой боковой поверхностью

Сила вырубки-пробивки пуансонами с различной формой рабочих граней регистрировалась по показаниям разрывной машины. На рис. $3(\mathrm{a}$, б) показаны результаты исследований. Из сравнения полученных результатов следует, что сила вырубки-пробивки возрастает от минимального значения $P=50$ кН при пуансоне с односторонним наклоном режущей кромки до $P=120$ кН при плоском пуансоне. Установлено, что сила вырубки-пробивки, $\mathrm{a}$, следовательно, и сопротивление разделению (сдвигу) $\sigma_{c д}$ существенно зависят от состояния рабочей поверхности рифленого пуансона, характеризуемого шагом рифлений. Шаг рифлений сказывает влияние на силовые параметры. Они возрастают от $P=90$ кН $(t=0,5$ мм $)$ до $P=115$ кН $(t=1,0$ мм). Эти данные согласуются с результатами исследований С. 3. Юдовича и И. И. Горбенко [4].

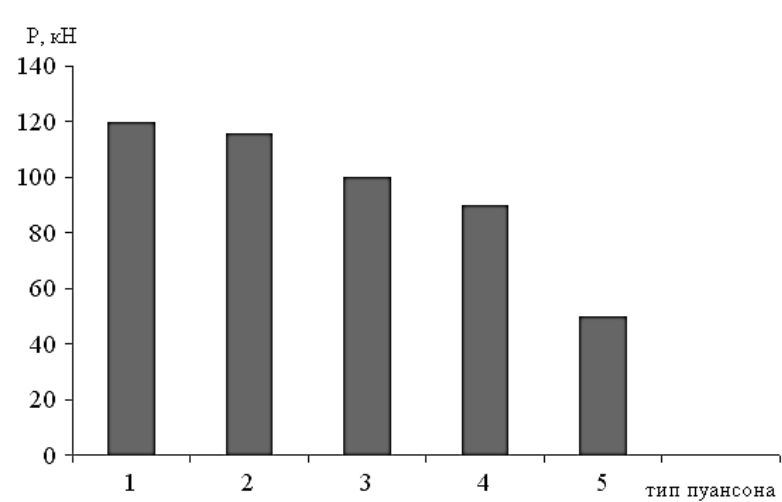

$\mathrm{a}$

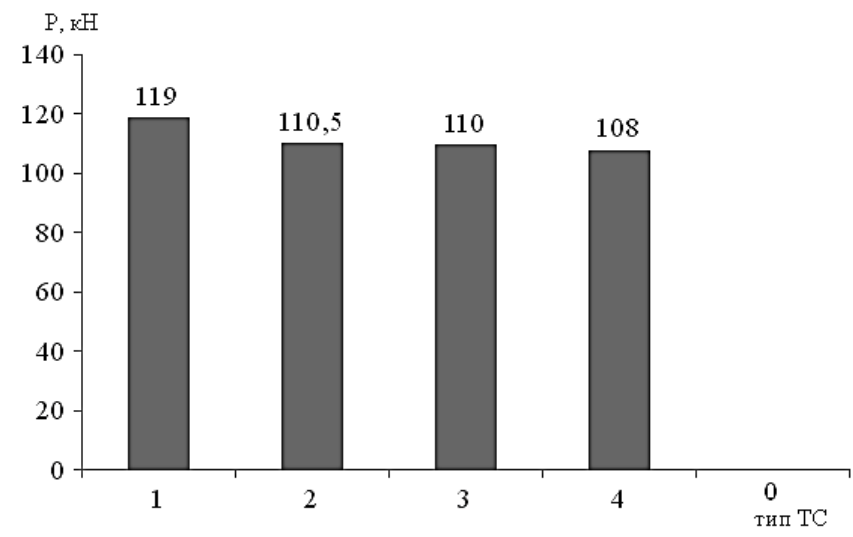

6

Рис. 3. Изменение усилия вырубки-пробивки:

$\mathrm{a}-$ пуансонами с различной формой рабочих граней режущей кромки; б - плоским пуансоном с применением различных ТС 
Кроме того, на деталях, вырубленных рифленым пуансоном, ярко выраженной границы между пояском смятия и остальной поверхностью нет. Это указывает на существенное снижение удельных нагрузок в зоне контактного пояска при вырубке рифленым пуансоном, a, следовательно, и на снижение силовых и энергетических затрат на разделение штампуемого материала. Применение рифленых вырубных и пробивных пуансонов, как показали производственные исследования, обеспечивает повышение износостойкости в 3-4 раза [4].

Применяя плоский пунсон, провели исследования по влиянию технологической смазки на силовые параметры при вырубке-пробивке. В качестве смазки применяли масло И-50, Олон-10 \%, графито-фосфатный препарат (ГФП) и «Укринол-8». На рис. 3 представлены результаты исследования, из которых следует, что применение указанных смазок весьма незначительно влияет на силовые параметры при разделительных операциях.

Наибольший эффект получен при смазке «Укринол-8» (снижение силы вырубки на 10 \%).

\section{ВЫВОДЫ}

Установлено, что стойкость инструмента при разделительных операциях в определенной степени зависит от удельных давлений на рабочие грани, что позволяет, получив данные по энергосиловым параметрам вырубки-пробивки, судить о предлагаемой стойкости.

Показано, что при вырубке круглых стальных деталей сила вырубки зависит от формы рабочих граней пуансона. Вырубка пуансоном с односторонним наклоном режущих кромок в 2,4 раза снижает силу вырубки по сравнению с вырубкой плоским пуансоном. При вырубке рифленым пуансоном (шаг рифленый $t=0,5$ мм) сила вырубки в 1,3 раза меньше, чем при вырубке плоским пуансоном.

Применение технологических смазок (ТС) при разделительных операциях позволяет снизить силу вырубки на 10 \% (ТС «Укринол-8»). Качество поверхности вырубленных деталей во всех случаях удовлетворительное. При вырубке с применением ТС высота блестящего пояска несколько больше.

\section{СПИСОК ИСПОЛЬЗОВАННОЙ ЛИТЕРАТУРЫ}

1. Зубиов М. Е. Стойкость итампов / М. Е. Зубиов, В. Д. Корсаков. - М. : Маииностроение, 1971. - 201 с. 1976. $-208 c$

2. Михаленко Ф. П. Стойкость разделительных штампов / Ф. П. Михаленко. - М. : Машиностроение,

3. Фукс-Рабинович Г. С. Основные факторы, определяющие стойкость инструмента при вырубке / Г. С. Фукс-Рабинович, А. Н. Кузнеияов, В. Ф. Моисеев // Кузнечно-итамповочное производство. - 1990. - № 2. C. $16-17$.

4. Ковка и штамповка : справочник в 4 томах. Том 4. Листовая штамповка / Под ред. А. Д. Матвеева. М. : Машиностроение, 1985-1987. - 544 с.

\section{REFERENCES}

1. Zubcov M. E. Stojkost'shtampov/M. E. Zubcov, V. D. Korsakov. - M. : Mashinostroenie, 1971. - 201 s.

2. Mihalenko F. P. Stojkost' razdelitel'nyh shtampov / F. P. Mihalenko. - M. : Mashinostroenie, 1976. - 208 s.

3. Fuks-Rabinovich G. S. Osnovnye faktory, opredeljajushhie stojkost' instrumenta pri vyrubke / G. S. FuksRabinovich, A. N. Kuznecov, V. F. Moiseev // Kuznechno-shtampovochnoe proizvodstvo. - 1990. - № 2. - S. 16-17.

4. Kovka i shtampovka : spravochnik v 4 tomah. Tom 4. Listovaja shtampovka / Pod red. A. D. Matveeva. - M. : Mashinostroenie, 1985-1987. - 544 s.

Каргин Б. С. $\quad$ - канд. техн. наук, проф. ГВУЗ «ПГТУ»;

Каргин С. Б. - - канд. техн. наук, доцент ГВУЗ «ПГТУ»;

Ашихмин А. Г. - студент ГВУЗ «ПГТУ».

ГВУЗ «ПГТУ» - Государственное высшее учебное заведение «Приазовский государственный технический университет», г. Мариуполь.

E-mail: alexander.anishchenko@gmail.com 